\title{
The Enforcement of Administrative Law to Violation of Building Construction Permit Requirements for Business Activity
}

\author{
Enny Agustina ${ }^{1}$ \\ \{ennyagustinadua@yahoo.com ${ }^{1}$ \} \\ Kader Bangsa University, Faculty of Law, Palembang, South Sumatra, Indonesia ${ }^{1}$
}

\begin{abstract}
The Government, especially the Regional Government, has regional autonomy as the authority or power in a region that regulated and managed for the benefit of the region itself. The government in regulated and control used of land for business has various policies, which is one of Building Construction Permit issued by the City / Regency Government. There is a problem about Building Construction Permit that is the inconsistency of laws and regulations with social facts that occur in the community. From preliminary research results in Civil Sservice Police Unit and there are still many buildings for business activities that did not have Building Construction Permit. This research was data collection method was used library research (Library Research). Research Purposes was The Enforcement of Administrative Law to Violation of Building Construction Permit Requirements for Business Activities and to known The Government's Effort to Enforce Administrative Law to Violations of Building Construction Permit for Business Activities. .The result of this research was The Civil Service Police Unit had done well the enforcement of administrative law. This is because the enforcement process is based on public order, the officers of Civil Service Police Unit seen that the location of the building for business activities was appropriate with the Spatial Plan.
\end{abstract}

Keywords: Enforcement Law, State Administrative Law.

\section{Introduction}

Every society has the right to build and open a business. However, these rights were accompanied by procedures and obligations that fulfilled by the community. The Government, especially the Regional Government, has regional autonomy as the authority or power in a region that regulated and managed for the benefit of the region itself. The government in regulated and control used of land for business has various policies, which is one of Building Construction Permit issued by the City / Regency Government. There is a problem about Building Construction Permit that is the inconsistency of laws and regulations with social facts that occur in the community. From preliminary research results in Civil Sservice Police Unit and there are still many buildings for business activities that did not have Building

Construction Permit. Based on the background of the problem, it submitted and formulated the research title: "Enforcement of Administration Law to Violation of Building Construction Permit Requirements for Business Activity". 


\section{The Problem}

1. How is The Enforcement of Administrative Law to Violation of Building Construction Permit Requirements for Business Activities?

2. What is The Government's Effort to Enforce Administrative Law to Violations of Building Construction Permit for Business Activities?

\section{Purpose Reseacrh}

1. To Known The Enforcement of Administrative Law to Violation of Building Construction Permit Requirements for Business Activities.

2. To Known The Government's Effort to Enforce Administrative Law to Violations of Building Construction Permit for Business Activities.

\section{Literature Review}

\section{A. The Enforcement of Administrative Law.}

The term law enforcement is often used to translate the term law enforcement (C.S.T, 2002) which is a series of efforts, processes, and activities to make the law work as it should. According to Jimlly Ashiddiqie, an attempt to enforce or function of legal norms as a behavioral guide in the traffic or legal relationships in public life and state.

In the enforcement of administrative law is known to preventive law enforcement and repressive law enforcement (Tjokoaminoto, 1995). The enforcement preventive law was a series of action attempts, which is intended as a prevention of no violation or deviation of existing requirements. The enforcement preventive law was done by providing a provision for understanding and awareness for the society as well as parties related to licensing issues in order to understand what the legislator wants is. While repressive law enforcement was done when there had a violation of law, especially regarding the matter of licensing.

In the State of Administrative Law, the use of administrative sanctions was the application of government authority, where this authority came from the rules of the State Administrative Law written and unwritten. In general, authorize the government to establish the norms of the Law.

State Administrative, also accompanied by given authorize the enforcement of norms through the imposition of sanctions for those who violate the norms of The State Administrative Law. There are some typical administrative sanctions among others:

1. Bestuursdwang (Government coercion);

2. Recall of decision (provision) profitable (permits, payments, subsidies);

3. Imposition of administrative fine;

4. Imposition of forced money by the government (dwangsom).

\section{B. Violations}

The violations are coming from criminal law, civil law and administrative law. In terms of criminal law violations of criminal law norms immediately is taken action by the court without 
any complaints from the party who harmed. While the violation in terms of civil law is a violation of civil law norms just taken action by the court after a complaint from the parties concerned. According to administrative law is a violation of the requirements of law and regulate governing the implementation of the interests and general welfare of the State and the actions of officials or administrative bodies of State which contradicts with the general principles of good governance (MD, 2006).

\section{Building Construction Permit for Business Activities}

Building Construction Permit was a permit given by the Regional Government to the owner of a stand-alone building and / or building a stand-alone infrastructure to build new, transforming, expanding, reducing and / or caring for buildings and / or building of standalone infrastructure in accordance with administrative requirements and applicable technical requirements.

Susanta said that a permit given by the regional government to a person, a group of persons or bodies to build in the framework of the utilization of space appropriate with the permit given because it fulfill the requirements of various aspects, land, technical, planning and environment. Every person who owns a building had a Building Construction Permit. Building Construction Permit is the beginning of a letter from the regional government that the building owner constructed the building appropriate with the stipulated function and based on the technical plan of the building approved by the regional government. (Sutedi, 2010).

Understanding business activities in the Big Indonesian Dictionary are an activity by directing the energy, mind, or body to achieve a purpose.

In Indonesia is known for small and medium micro enterprises. According to the Law of the Republic Indonesia Number 20 Year 2008 on micro, small and medium enterprises the definition is:

1) Micro Enterprises is productive businesses owned by natural persons and / or business entities that fulfill the criteria of micro-enterprises, and includes:

a. Having a net worth of at most Rp. 50,000,000, (fifty million rupiah), excluding land and business buildings, or

b. Having annual sales of at most Rp. 300,000,000, (three hundred million rupiah).

2) Small-scale business is a stand-alone productive economic enterprise, conducted by an individual or business entity that is not a wholly owned subsidiary, controlled, and became a direct or indirect part of a medium-sized or large-scale business that fulfill the criteria of a small business as referred to in the law.

3) A medium-sized enterprise is a stand-alone productive economic enterprise, conducted by an individual or business entity that is neither a subsidiary nor a branch of a company owned, controlled, or partakers either directly or indirectly with a small business or a large business by the amount of wealth net or annual sales proceeds as stipulated in law. In general, these medium-sized businesses in bank finance are included in the credit segment with a loan value of Rp. 500.000.000, (five hundred million rupiah) up to a maximum of Rp. 5.000.000.000, (five billion rupiah). 


\section{Results And Discussion}

a. The Enforcement Administration Law to Violations of Building Construction Permit for Business Activities (Sukardja, 2014). Pamong Police Unit. The process of investigating the violation of regional regulations conducted when there are reports from the public or agency or findings in the field by the officers of Civil Service Police Unit, evidence of violation of regional regulations conducted investigation process. The investigation process was intended to find the element of infringement committed by the offender. After the data was valid or considered correct then made Report Events Violations of Regional Regulations made by Civil Servants Investigator. After the Report Events Violations of Regional Regulations conducted call offenders. This invocation used a summon letter was done up to 3 times. After the summons of the 3 Civil Service Investigators request assistance by the Police to take forcibly violators. After the Police pick up the offenders, it was taken to Civil Service Investigator's office or taken to the Police Station. And also after the letter summoned Civil Service Investigator officers issued a warning letter to violators without request assistance by the Police. The existence of this call had entered the realm of investigation. After the investigation by Civil Servant Investigator completed then the delegation to the Prosecutor through the police / police as the Coordinator of Supervisor of Civil Servant Investigator. After declared the complete file, so it was done delegation to conducted session.

The enforcement of administrative law to violation of Regional Regulation appropriate with Regional Regulation Number.3 Year 2012 about Organization and Work Procedure was conducted by Civil Service Police Unit. The authority given by the Regent to Civil Service Police Unit is in the form of authority sourced from the delegation's authority. The authority of the delegation is the authority of the government from one government organ to another. Civil Service Police Unit as a tool of regional government in maintaining and implementing peace and public order and enforcing regional law products. (Syaffie, 2003).

Process enforcement administrative law to violation of Building Construction Permit there are two: (Wijoyo, 2006)

a. Preventive

The preventive nature of enforcement administrative law is the prevention of law enforcement. Preventive law enforcement includes:

1. Socialization on the provisions of regional regulations

2. Integrated, monitoring and supervision in an integrated manner with Regional Device Work Unit. Civil Service Police Unit by conduct supervision to the buildings for these business activities directly plunge spaciousness by visit one by one building under construction and questioned related to Building Construction Permit.

3. Firm Actions. The firm action taken by Civil Service Police Unit is to impose administrative sanctions.

b. Repressive

The repressive nature of the enforcement of administrative law is law enforcement conducted after the violation of law. Repressive law enforcement includes: (dkk, 2011) Philipus M. Hadjon, et al. 2011, Introduction to Indonesian Administrative Law, Gajah Mada University Press, Yogyakrta.

1. Persuasive coaching

Persuasive coaching is a coached to change or influence one's behavior, so behave appropriate with the ordered (HR, 2013). 
The owner of the building that did not have Building Construction Permit after a persuasive coaching and then the building owner is summoned to Civil Service Police Office for question relate to the land used for the building, building permit, and building function. After owner of the building was questioned by Civil Service Police Officer made the news of the guidance event. This Civil Service Police Officer issued a coaching report and conducted persuasive coaching for 15 working days. (Santosa, 2015).

2. Warning letters

This warning letter is given to violators of the Building Construction Permit if persuasive coaching is ignored. This warning letter there are three times, that is (Yuni, 2008):

a) There are seven days. If the offender ignores the first warning letter then, there is a second warning letter;

b) Given for seven days. If the offender ignores the second warning letter then, there is a third warning letter;

c) This third warning letter is given for 3 days.

3. Execution termination and sealing

The function of this sealing is to avoid other violations of the building under construction. The sealing procedure is the third warning letter is ignored, officer of Civil Service Police Unit reads the warning letter in front of the building and the people in the building, and then the officer who seals the letter is assigned the sealing duty. (Siahaa, 2008).

4. Dismantling of buildings

The demolition of the building was initially handed over to owner of the building to dismantle the building itself. The goal is given an opportunity to owner of the building to retrieve the items used again. If owner of the building did not dismantle the building on the 7th day then officer of Civil Service Police Unit dismantle own building which has no Building Construction Permit.

b. Government Efforts to Enforcement of Administrative law to Violation of Building Construction Permit for Business Activities

1. The Office of Investment and Integrated Licensing socialize to the community Building Construction Permit. To socialize control the Building Construction Permit for business activities of the office of Investment and Integrated Licensing invites small and medium entrepreneurs, headman, Family Welfare Development or usually referred to as the Family Welfare Development Team is usually a police officer from the Sector Police or the Rayon Military Command.

2. Industry, trade, cooperatives, micro, small and medium enterprises had tried to make a copy to every member who wants to register their business and did not have a Building Construction Permit.

3. Efforts of Civil Service Police Unit for violation of Building Construction Permit requirements for business activities are:

a. Socialization

b. Persuasive, monitoring and supervision in an integrated manner with the Regional Device Work Unit.

c. Firm Action 


\section{Conclusion}

Based on the previous description or based on the results of research on The Enforcement of Administrative Law to Violation of Building Construction Permit for Business Activities, the following conclusions were drawn:

1. The Civil Service Police Unit had done well the enforcement of administrative law. This is because the enforcement process is based on public order, the officers of Civil Service Police Unit seen that the location of the building for business activities was appropriate with the Spatial Plan.

2. Government efforts to the enforcement of administrative law to violations of Building Construction Permit for business activities of the Office of Investment and Integrated Licensing had conducted socialization to the community about Building Construction Permit. from the Department of Industry, Trade, Cooperatives, Micro, Small and Medium Enterprises had tried to make a copy to every member who wants to register their business and did not have Building Construction Permit, while from Civil Service Police Unit conducted coaching and / or socialization, and persuasive, monitoring and supervision in an integrated manner with the Regional Device Work Unit and Action Firm.

\section{References}

\section{Book:}

[1]. Adrian Sutedi. (2010). Licensing Law in Public Service Sector. Sinar Grafika Offset, Jakarta.

[2]. Ahmad Sukardja. (2014). State Administrative and State Administration in Perspective of Fikih Siyasah. Sinar Grafika. Jakarta.

[3]. Kansil C.S.T. (2002). Introduction to Law Science. Balai Pustaka, Jakarta.

[4]. Bintaro Tjokoaminoto. (1995). State Administration System of the Republic Indonesia. PT Ikrar Mandiriabadi, Jakarta.

[5]. Dwi Yuni. (2008). Practical Guide to Take care of IMB. Pustaka Grahatama, Yogyakarta.

[6]. Faculty of Law University of Atma Jaya Yogyakarta. (2015). Thesis Writing Guidance / Law. Yogyakarta.

[7]. Inu Kecana Syafiie. (2003). State Administration System of Republic Indonesia. Sinar Grafika Offset, Jakarta.

[8]. Kusno Wijoyo. (2006). Taking care of IMB and the problem. Pemko Bekasa, Jakarta.

[9]. Lukman Santosa. (2015). Local Government Law (Parsing Problems of Pemekaran Daerah PostReformation in Indonesia). Pustaka Pelajar, Yogyakarta.

[10]. Marihot Pahala Siahaa. (2008). Building Building Law in Indonesia. Raja Grafindo Persada, Jakarta.

[11].Moeljatno. (2008). Principles of Criminal Law. Rineka Cipta, Jakarta.

[12]. Mukti Fajar Nur Dewata and Yulianto Achmad. (2010). Dualism Penelitiasn Normative \& Empirical Law. Publisher Pustaka Pelajar, Yogyakarta.

[13].Philipus M. Hadjon, et al. (2011). Introduction to Indonesian Administrative Law. Gajah Mada University Press, Yogyakrta.

[14].Ridwan HR. (2013). State Administration Law. Publisher PT Raja Grafindo Persada, Jakarta.

[15].Sunarto. (2005). Local Taxes and Levies. AMUS Yogyakarta and Citra Pustaka, Yogyakarta.

[16].SF Marbun and Mahfud MD. (2006). Principles of State Administration Law. Liberty, Yogyakarta.

[17]. Susanta, Gatot. (2002). Easy to Take care of IMB. Asa Sukses, Jakarta.

[18].Rosidin Debt. (2015). Regional Autonomy and Decentralization. CV Pustaka Setia, Bandung.

[19].Sri Pudyatmoko Y. (2007). Law Enforcement and Protection in the Tax Sector. Salemba Four, Jakarta. 
Widiasarana Indonesia, Jakarta.

\section{Internet:}

[1]. http://jogja.tribunnews.com/2016/05/01/potensi-usaha-besar-sasaran-sensus-ekonomi-dilakukanglobal accessed Tuesday November 15, 2016, at 12:47 pm.

[2]. http://Kemalang.Klaten.info/2013/09/melihat-Klaten-dan-sejarahberdirinya.html?m accessed on 21 November 2016, at 13:53 pm.

[3]. https://Klatenkab.bps.go.id/linkTableStatis/view/id/10 accessed on November 14, 2016, at 18:13 $\mathrm{pm}$.

[4]. http://m.kompasiana.com/ratihsyifani.kompasiana.com/Kabupaten-Klaten-terancambangkrut_552bf4876ea834e5758b45a0 accessed on October 10, 2016, at 15:47 pm.

[5]. http://tarmizi.wordpress.com/ accessed Thursday September 8, 2016, at 23:09 pm.

[6]. http://www.academia.edu/8986598/HUKUM_PERIZINAN_materi accessed Tuesday September 27th, 2016, at 20:45 pm.

[7]. http://www.zonasiswa.com/2015/10/pengertian-pemerintahan-legislatif.htm accessed November 14, 2016, at $12: 35 \mathrm{pm}$.

[8]. Big Indonesian Dictionary in http://kbbi.web.id/langgar accessed Thursday September 8, 2016, at 22:40 pm.

[9]. Big Indonesian Dictionary at http://kbb.web.id/usaha accessed on 3 September 2016 at 14.50 wib.

[10].https://www.academia.edu/5090235/Hukum accessed Friday November 25, 2016, at. 10.03 wib.

[11].www.academia.edu/9308985/Hukum_Administrasi_Negara accessed Sunday 2 October 2016, at $15: 20 \mathrm{pm}$.

[12].www.Klatenkab.go.id/list-state/ accessed November 14, 2016, at 17:49 pm.

\section{Regulation of the Law of Republic Indonesia:}

[1]. The Constitution 1945 of State Republic Indonesia.

[2]. Law of the Republic Indonesia Number 23 Year 2014 on Regional Government, State Gazette of the Republic Indonesia Year 2014 Number 244, Supplement to State Gazette of the Republic Indonesia Number 5587.

[3]. Government Regulation Number. 36/2005 on the Regulation of the Implementation of Law of the Republic of Indonesia Number 28 Year 2002 concerning Building, State Gazette of the Republic of Indonesia Year 2005 Number 83, Supplement to State Gazette of the Republic of Indonesia Number 4532.

[4]. Regional Regulation of Regency of Municipality Number. 15 Year 2011 on Building and Building, District Gazette of Regency of Klaten Year 2011 Number 15, Supplement to Regional Gazette of Regency of Klaten Number 70.

\section{Thesis / Dissertation:}

[1]. Mareci Susi Afrisca Sembiring. (2015). Effectiveness of Planning Advice in Building Permit Service In Kota Pematangsiatar. Thesis, Strata-I. Atma Jaya University Yogyakarta.

\section{Brochure:}

[1]. Brochure of Integrated Office of Investment and Licensing of Klate Regency 